\title{
Analysis on Translation of Children's Literature from the Perspective of Functional Equivalence Theory-Based on Tale in Orange
}

\author{
Linling Zhong \\ The University of Nottingham Ningbo China, Ningbo 315000, China \\ naomi_zll@163.com
}

Keywords: children's literature, functional equivalence theory, meaning, style, culture.

\begin{abstract}
Children's literature is a special type of literary works. Translation of children's literature plays a decisive role in creating children's fantastic spiritual world. When translating children's literature, the translator must take children's special physical and psychological characteristics into consideration and bear in mind that the target readers are children and and the translation should be child-orientated and vivid. This paper aims at analyzing the translation of Tale in Orange and studying how to achieve equivalence between the source text and the target text from the perspective of functional equivalence theory. Through three aspects of equivalence-equivalence in terms of meaning, equivalence in terms of style and equivalence in terms of culture. This paper explores the reasonable strategies for translating children's literature and proves that functional equivalence theory is applicable in guiding the translation of children's literature.
\end{abstract}

\section{Introduction}

The source text is a children's book named Tale in Orange. It is a fairy tale of a girl called Marianna who loves everything about orange. With a magic turn of events, she finds herself in an orange land where her imaginations become real and she will explore this new place. This story is full of fantastic and vivid descriptions.

The translation is from the perspective of functional equivalence theory to cater to children's psychological expectation and language level and help children to read and understand this interesting story. There are two features of children's literature: figurativeness and conciseness. Thus, the analysis of the story is from three aspects of equivalence: equivalence in terms of meaning, equivalence in terms of style and equivalence in terms of culture.

\section{Equivalence in Terms of Meaning}

Translating consists in reproducing in the receptor language the closest natural equivalent of the source-language message, first in terms of meaning and secondly in terms of style. [Nida 1969:12] The target language should answer the purpose of child's taste and reproduce the author's writing. The priority of translation is to convey the meaning of the source text.

\section{Example 1}

She was in an orange car... with her dad and mom. A strange music was all around them. You could say it was purple... With tales in red and yellow swimming inside her.

玛丽安娜和爸爸妈妈在一辆橘子小车里。神奇的音乐一直围绕着他们。这是一个华丽的梦。 在梦里, 那些红黄色彩编织的故事都徜徉在她的脑海里。

The phrase “orange car" can be translated into “橙色的小车”, but according to equivalence in terms of meaning, “橘子小车”will give children a feeling that the car is made of orange, just like Cinderella's pumpkin carriage. Besides, this sentence is in the beginning of the story, thus the translation should be appealing to children.

\section{Example 2}

An orange half-moon leaned into the sky's background... Tomorrow they were going on a trip. 弯弯的月亮就像一襄橘子挂在空中。明天橘子旅行还将继续。 
The author uses the phrase "an orange half-moon" to describe a crescent moon. The direct meaning is “像橘子一样的半月”. However, the shape of orange is round as we all know. According to the shape, the moon is not round like an orange. Here the author expresses a meniscus which looks like a piece of arched orange instead of an orange. Therefore, the translation becomes “弯弯的月亮就像 一襄橘子”, using simile in the translation due to the source text uses metaphor so that the translation can achieve equivalence.

\section{Equivalence in Terms of Style}

Though style is secondary to content, it is nevertheless important. [Nida 1969:13] Translation style focuses on the style of the source text and translators must do some adaptability to match appropriateness. The aim is to make the source text afterlife.

\section{Example 3}

She believed this Lorca - mom's favorite poet- with the most beautiful gaze she had ever seen, was definitely "Portokalian". For who else could write such a beautiful song about an orange tree?

她认定这个罗卡就是橘子园的人。因为只有这位母亲钟爱的诗人，这位双目美丽动人的诗 人，才能写出如此美妙的橘子之歌。

This is a long subordinate clause. The translation transforms it into short sentences with a structure “只有...才...” to indicate the requisite qualifications of Lorca to be "Portokalian". This structure is making equivalence in terms of style between the rhetorical questions in source language and the target language. The aim of the subordinate clause is to highlight how wonderful Lorca is to be a "Portokalian" and the function of “只有...才..." in translation is emphasis.

\section{Equivalence in Terms of Culture}

In children's literature, there are some specific words and objects in foreign culture. This would be a difficult part for children to understand. Children are not familiar with other local culture and objects. As a result, the translation of this kind of sentence and words in children's literature is a trans-cultural activity. I add some annotations to make children get some knowledge of a foreign land and at the same time make the translation understandable.

\section{Example 6}

She liked everything: even the unbelievable food. The paella was orange and delicious.

玛丽安娜喜欢这儿的一切, 连那些奇奇怪怪的食物也喜欢。西班牙杂烩菜饭（由大米、鸡 肉、鱼肉和蔬菜用平底锅烹制而成）看起来是橙色的，非常美味。

The word “paella” in dictionary is “西班牙杂烩菜饭”. Concerning about children's knowledge background, the translation cannot simply be the original meaning. Annotating what is the paella and describing it with food that children are familiar with is a good tactic to translate. The annotation can help children learn more about foreign culture.

\section{Literature Review}

Functional equivalence theory is put forward by Eugene Nida. He developed his theory from his own practical translation work of Bible. There are "two basic orientations" or "types of equivalence": (1) formal equivalence and (2) dynamic equivalence. [Nida 1964a:159] Formal equivalence focuses attention on the message itself, in both form and content ... One is concerned that the message in the receptor language should match as closely as possible the different elements in the source language. [Nida 1964a:159] Dynamic, or functional equivalence is based on what Nida calls "the principle of equivalent effect", where "the relationship between receptor and message should be substantially the same as that which existed between the original receptors and the message". [Nida 1964a:159] The success of the translation depends on achieving equivalence, which means the response of the target language readers is the same with the source language readers. 


\section{Summary}

Through the translation analysis of Tales in Orange, this paper finds that the language of children's literature is not difficult, but it is hard to make equivalence between the source text and the target text. Functional equivalence theory has instructive significance practically. The three aspects of equivalence are frequently used in the translation and this paper also discusses how to use these three aspects of equivalence to meet the translation aim: equivalence in terms of meaning, equivalence in terms of style and equivalence in terms of culture. These are also applicable in other children's literature due to the fact that children's literature has similar features and language style. Authors tend to use simple structure and rhetoric sentences to convey child interest. In addition, the translator should use common vocabulary for children and have some cultural background knowledge to reach better functional equivalence.

\section{References}

[1] Nida, E. A. (1964). Toward a science of translating: with special reference to principles and procedures involved in Bible translating. Brill Archive.

[2] Nida, E. A. (1969). Language and Culture: Contexts in Translating. Shanghai Foreign Language Education Press, 91, 92.

[3] Liao Qiyi\& Guo Jianzhong. (2000). Culture Conception and Translation. Beijing: China Translation Corporation, 173-175.

[4] Wang Zuoliang. (1984). Culture Comparison in Translation. Chinese Translators Journal(1), 2-6

[5] Zhao Sihua. (2011). A Discussion on Nada's Equivalence Theories in the Translation of Children's Literature_A Study Based on the Chinese Translation of Diary of a Wimpy Kid.

Science \& Technology Information. 136-137 